\title{
Clinico-Pathological Findings in Myeloid Malignancies: A Single Center Experience
}

\author{
Faheem Ahmed Memon, Amir Iqbal Memon, Pushpa, Nisar Ahmed, \\ Roohi Nigar, Ikramdin Ujjan
}

\section{ABSTRACT}

INTRODUCTION: Myeloid malignancies are clonal disorders of hematopoietic stem/precursor cells. The criteria for the diagnosis of acute myeloid leukemia (AML) are based on morphological cytogenetic and flow-cytometric findings. The prognostic outcome with intensive chemotherapy is better than with non-intensive treatment.

PURPOSE/OBJECTIVES: To determine the frequency of various clinical \& pathological findings in myeloid malignancies.

STUDY DESIGN: Cross sectional descriptive study.

PLACE AND DURATION OF STUDY: The study was carried out at Department of Pathology from October 2014 to December 2016.

MATERIAL/PATIENTS AND METHODS: Detailed history, clinical and pathological findings recorded on a pre-designed proforma including bone marrow reports was evaluated.

RESULTS: During period of study, 351 proformas including bone marrow reports were evaluated, from which 49 (30 males and 19 females; age ranges between 03 months to 60 years) were diagnosed as myeloid malignancies. The distribution of myeloid malignancies were acute myeloid leukemia $(n=21)$, chronic myeloid leukemia $(n=14)$, acute myelodysplastic syndrome $(n=3)$, myeloproliferative neoplasms $(n=3)$, myelofibrosis $(n=2)$, myeloid hyperplasia $(n=2)$, acute promyelocytic leukemia $(n=2)$, myelomonocytic leukemia $(n=1)$, and transient abnormal myelopoiesis $(n=1)$. The main presenting complaints were fever and weight loss, whereas splenomegaly was the most common finding on clinical examination. The commonest laboratory finding was anemia followed by leukocytosis; while 10 patients showed pancytopenia.

CONCLUSION: AML with fever and bicytopenia is the commonest myeloid malignancy in our series.

KEY WORDS: Acute myeloid leukemia, Myelodysplastic syndrome, splenomegaly.

This article may be cited as: Memon FA, Memon Al, Pushpa, Ahmed N, Nigar R, Ujjan I. Clinico-Pathological Findings in Myeloid Malignancies: A Single Center Experience. J Liaquat Uni Med Health Sci. 2017;16(01):49-52. doi: 10.22442/jlumhs. 171610505

\section{INTRODUCTION}

Acute myeloid leukemia (AML) is the most frequent acute leukemia in adult persons. Myeloid malignancies are clonal disorders of hematopoietic stem/ precursor cells. It includes the cells related to the granulocyte (neutrophils, eosinophils and basophils), monocytes or macrophage, erythroid or erythrocytes. Based on morphology, immunohistochemistry, cytogenetic and clinical characteristics, World Health Organization (WHO) has classified myeloid malignancies into five main categories i.e. Acute Myeloid Leukemia (AML), myelodysplastic syndromes (MDS), myeloproliferative neoplasms (MPN) which include chronic myeloid leukemia (CML) and non- chronic myeloid leukemia [polycythemia vera $(\mathrm{PV})$, essential thrombocythemia (ET) and primary myelofibrosis (PMF)], myelodysplastic and myeloproliferative (MDS/MPN) neoplasms and myeloid neoplasms concomitant with eosinophilia and irregularities of growth factor receptors. ${ }^{1-3}$.

Greatest chromosomal translocations as familiar as alterations in the genes committed in hematopoietic proliferation and differentiation arise in the accruement of poorly differentiated myeloid cells. AML is a highly diverse disease; although cases can be divided into favorable, intermediate and high-risk groups supported on their cytogenetic and molecular abnormalities, prognosis within these categories vary widely. ${ }^{4,5}$

Myeloid malignancies may exist in the peripheral blood and bone marrow. Most of the myeloid malignancies are well-thought-out malignant while other myeloid disorders are non-malignant or pre-leukemia blood conditions with a potential to evolve into malignant disease ${ }^{6}$.

Acute leukemia is a diverse group of hematological 
malignancies characterized by clonal development of immature myeloid or lymphoid precursors (blasts). Etiology of acute leukemia has been in focus since long and infection is a proposed etiology for several hematological malignancies ${ }^{7}$.

Chronic myeloid leukemia (CML) is a clonal myeloproliferative neoplasm (MPN), characterized by increase explosion of myeloid cells predominantly granulocytic series in the peripheral blood and bone marrow. $^{8}$

Myelodysplastic syndrome (MDS) is a cluster of disorders characterized by peripheral blood cytopenias in the presence of hypercellular or normocellular bone marrow with dysplastic features and has increased risk into leukemic conversion ${ }^{4}$.

Myeloproliferative neoplasms (MPN) include primary Myelofibrosis, essential thrombocytemia and polycythemia vera.

Acute promyelocytic leukemia (APML/APL) is the M3 subtype of acute myelogenous leukemia (AML), a malignancy of the leukocytes. In APL, there is atypical progress of undeveloped granulocytes called promyelocytes.

Transient abnormal myelopoiesis (TAM) or transient leukemia is defined as clonal myeloproliferation and considered by mingling megakaryoblasts in the peripheral blood.

Objective: To study the Clinical \& Pathological findings in myeloid malignancies.

Study Design: cross sectional descriptive study.

Place and Duration of Study: It was carried out at Department of Pathology from October 2014 to December 2016.

\section{MATERIAL/PATIENTS AND METHODS}

A total of 351 pre-designed proforma of bone marrow reports and detailed history, clinical and pathological findings were evaluated. Patients of all ages, ethnic groups and either gender were evaluated. In case of a child, father was interviewed. All particulars like age, gender, address and detailed history recorded on a pre-designed proforma of every patient. Detailed clinical examination with particular emphasis on hematological examination was performed on each patient.

A clinical diagnosis was made, based on history and hematological findings of physical examination. Bone marrow aspiration was performed from posterior iliac spine. In addition to routine examination after staining with Leishman stain, bone marrow slides were also stained with iron stain. Trephine biopsy was also performed through Jamshidi needle ${ }^{9}$ where required and immunohistochemistry was done where indicated. Blood sample for complete blood count (CBC) was taken from every patient and $\mathrm{CBC}$ was done on $\mathrm{XN}$ 1000 5-parts fully automatic analyzer by Sysmex Japan. Blood film examination for cell morphology was performed after staining with Leishman Stain.

\section{RESULTS}

Among the 351 study patients, 49 (30 males and 19 females, age ranged between 03 months to 60 years) were diagnosed as myeloid malignancies which included AML $(n=21), \operatorname{CML}(n=14)$, MDS $(n=03), M P N$ $(n=03)$, myelofibrosis $(n=02)$, Myeloid hyperplasia $(n=02)$, APML $(n=02)$, myelomonocytic leukemia $(n=01)$ and transient abnormal myelopoiesis $(n=01)$. The main presenting complaints were fever and weight loss. Splenomegaly was the most common finding on clinical examination. The commonest laboratory finding was anemia followed by leukocytosis, 10 patients had pancytopenia.

FIGURE I:

\section{FREQUENCY OF MYELOID MALIGNANCIES}

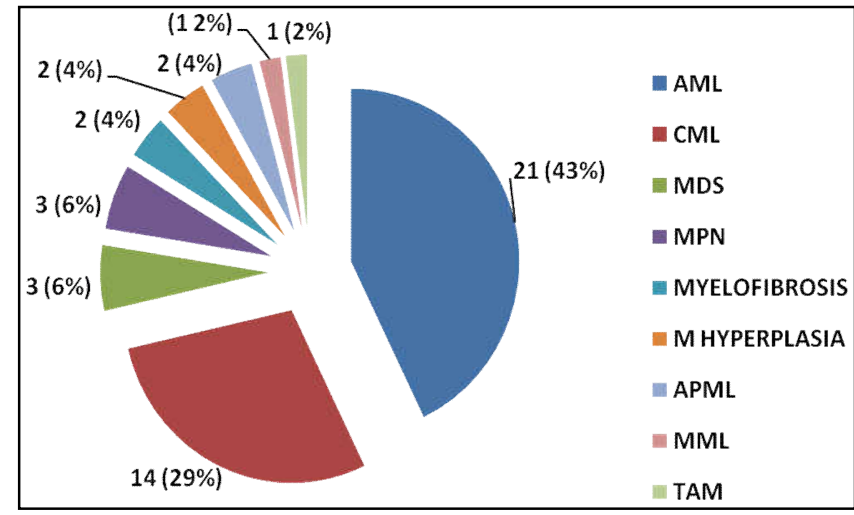

FIGURE II: AGE AND GENDER DISTRIBUTION OF DIFFERENT TYPES OF MYELOID MALIGNANCIES

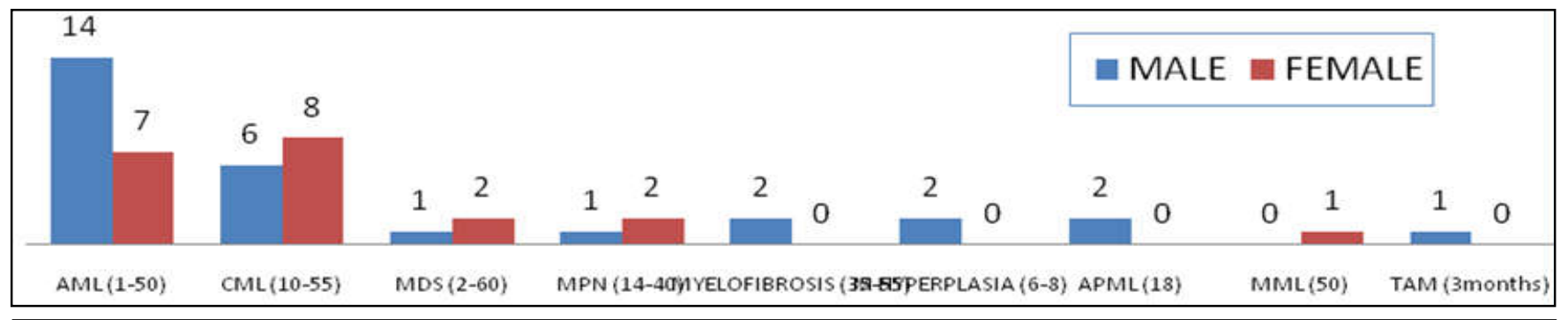


Faheem Ahmed Memon, Amir Iqbal Memon, Pushpa, Nisar Ahmed, Roohi Nigar, Ikramdin Ujjan

\section{TABLE: PRESENTING COMPLAINTS, PHYSICAL EXAMINATION AND LABORATORY FINDINGS IN DIFFERENT MYELOID MALIGNANCIES}

\begin{tabular}{|c|c|c|c|}
\hline $\begin{array}{c}\text { Diagnosis } \\
\text { ( } \mathrm{N}=\text { Number of Patients) }\end{array}$ & Presenting Complaints & Physical Examination & Laboratory Findings \\
\hline $\begin{array}{l}\text { Acute Myeloid Leukemia } \\
\qquad(\mathrm{N}=21)\end{array}$ & \begin{tabular}{|l} 
Fever \\
Weakness \\
Weight Loss \\
Pain In Abdomen \\
\end{tabular} & $\begin{array}{l}\text { Pallor } \\
\text { Lymphadenopathy } \\
\text { Hepato-splenomegaly }\end{array}$ & $\begin{array}{l}\text { Bicytopenia } \\
\text { Anemia } \\
\text { Leukocytosis } \\
\text { Pancytopenia } \\
\end{array}$ \\
\hline $\begin{array}{l}\text { Chronic Myeloid Leukemia } \\
\qquad(\mathrm{N}=14)\end{array}$ & $\begin{array}{l}\text { Weakness } \\
\text { Pain In Abdomen } \\
\text { Fever }\end{array}$ & $\begin{array}{l}\text { Splenomegaly } \\
\text { Pallor }\end{array}$ & $\begin{array}{l}\text { Anemia } \\
\text { Leukocytosis } \\
\text { Increase Platelets }\end{array}$ \\
\hline $\begin{array}{l}\text { Myelodysplastic Syndrome } \\
\qquad(\mathrm{N}=03)\end{array}$ & $\begin{array}{l}\text { Fever } \\
\text { Weakness } \\
\text { Weight Loss }\end{array}$ & Pallor & Pancytopenia \\
\hline $\begin{array}{c}\text { Myeloproliferative Disorder } \\
\text { /Neoplasms } \\
(\mathrm{N}=03)\end{array}$ & $\begin{array}{l}\text { Fever } \\
\text { Weakness } \\
\text { Weight Loss }\end{array}$ & Splenomegaly & $\begin{array}{l}\text { Leukocytosis } \\
\text { Anemia }\end{array}$ \\
\hline $\begin{array}{l}\text { Myelofibrosis } \\
\quad(\mathrm{N}=02)\end{array}$ & $\begin{array}{l}\text { Fever } \\
\text { Weakness } \\
\text { Weight Loss } \\
\end{array}$ & Hepato-Splenomegaly & $\begin{array}{l}\text { Pancytopenia } \\
\text { Anemia+ Leukocytosis }\end{array}$ \\
\hline $\begin{array}{l}\text { Myeloid Hyperplasia } \\
\qquad(\mathrm{N}=02)\end{array}$ & $\begin{array}{l}\text { Fever } \\
\text { Weakness } \\
\text { Weight Loss }\end{array}$ & & $\begin{array}{l}\text { Pancytopenia } \\
\text { Platelets decrease }\end{array}$ \\
\hline $\begin{array}{l}\text { Acute Promyelocytic Leukemia } \\
\qquad(\mathrm{N}=02)\end{array}$ & $\begin{array}{l}\text { Fever } \\
\text { Weakness }\end{array}$ & & $\begin{array}{l}\text { Pancytopenia } \\
\text { Bicytopenia } \\
\end{array}$ \\
\hline $\begin{array}{l}\text { Myelomonocytic } \\
\text { Leukemia( } \mathrm{N}=01)\end{array}$ & $\begin{array}{l}\text { Fever } \\
\text { Weakness }\end{array}$ & & Bicytopenia \\
\hline $\begin{array}{l}\text { Transient Abnormal Myelopoiesis } \\
\qquad(\mathrm{N}=01)\end{array}$ & $\begin{array}{l}\text { Fever } \\
\text { Weakness } \\
\text { Weight Loss }\end{array}$ & Hepato-splenomegaly & Bicytopenia + Leukocytosis \\
\hline
\end{tabular}

\section{DISCUSSION}

The limitation of this study include lack of cytogenetic testing, as most of the studies has revealed that karyotyping and FISH sensitivities along with RQ-PCR are most important ${ }^{10}$. The youngest patient of this series was six months old while the eldest patient's age was 60 years, eldest patient age is identical as mentioned in other study ${ }^{11}$. Siegel in 2012 showed that the incidence increases from 1.3 per 100,000 for those below 65 years of age to 12.2 cases per 100,000 for above 65 years of age. AML was overall the commonest leukemia in our study; it is the second most common type of leukemia in the United States of America while in most of the Pakistani literature have also shown AML to be the commonest leukaemia ${ }^{12}$.A study by Smith et al reported myeloid cancers are male dominant, and both children and adults equally affected, a finding which also reflect in our study.

For the diagnosis and to follow response from treatment in various malignancies cytogenetic, $\mathrm{FISH}$, and RQ-PCR tests are used in patients but all of these tests have different sensitivity for detection and monitoring of malignant cells, several studies have also shown that leukemia cells can be found in the circulation when complete cytogenetic response is achieved. Real time PCR as compared to cytogenetics is less mind-numbing, gives fast results and not requires several sampling due to culture failure and can be done on peripheral blood samples; local and international studies also suggest that PCR is comparable with cytogenetics. It has been suggested that frequency of myeloid malignancies occurs when pathogens are present in a prone population and other important immunological factors, acute or reactivated chronic infection could be responsible for myeloid malignancies.

The formation of a specific nomenclature constituting homogeneous pathological and physiological entities is a major area in hematology. It depends heavily on molecular data; which start with the karyotyping and sustained with gene expression profiles as gene mutations will nicely complete the scenario. Other factors such as microRNAs and long non-coding RNAs status, methylation profiles and histone marks may have to be integrated too. Most of the studies have shown that gene mutations have certainly a major impact on diagnosis of myeloid diseases.

This is single-center cross-sectional survey based on the Pakistani population; the results of this analysis cannot be generalized to other geographical regions of the world ${ }^{13}$. 


\section{LIMITATIONS}

It is suggested that larger multicentre studies be carried employing molecular diagnostic tools besides the conventional ones with an effort to gather additional information of the clinical and pathological spectrum of myeloid malignancies.

\section{CONCLUSION}

AML with fever and weight loss / weakness besides bicytopenia is the commonest myeloid malignancy in our series.

\section{REFERENCES}

1. Tong H, Liu Z, Lu C, Wang Q. Clinical and laboratory features of adult biphenotypic acute leukemia.Asia Pac J ClinOncol. 2013;9(2):146-54.

2. Kumar S, Yedjou CG, Tchounwou PB. Arsenic trioxide induces oxidative stress, DNA damage, and mitochondrial pathway of apoptosis in human leukemia (HL-60) cells. J Exp Clin Cancer Res. 2014;33:42.

3. Gocek E, Marchwicka A, Baurska H, Chrobak A, Marcinkowska E. Opposite regulation of vitamin D receptor by ATRA in AML cells susceptible and resistant to vitamin D-induced differentiation. J Steroid Biochem Mol Biol. 2012;132(3-5):220-6.

4. Murati A, Brecqueville $M$, Devillier $R$, Mozziconacci M, Gelsi-Boyer V, Birnbaum D. Myeloid malignancies: mutations, models and management. BMC Cancer. 2012;12:304.

5. Shih AH, Abdel-Wahab O, Patel JP, Levine RL. The role of mutations in epigenetic regulators in myeloid malignancies. Nat Rev Cancer. 2012;12 (9):599-612.
6. Ntziachristos $\mathrm{P}$, Mullenders $\mathrm{J}$, Trimarchi $\mathrm{T}$, Aifantis I. Mechanisms of epigenetic regulation of leukemia onset and progression. Adv Immunol. 2013;117:1-38.

7. Ehsan A, Khan M.A, Lone A, Arif M, Asif M.J, Riaz S. Acute Myeloid Leukemia, Epidemiology and Seasonality, A Single Center Experience. Biomedica. 2015;31(3):219-22.

8. Tashfeen S, Ahmed S, Bhatti FA, Ali N. Real Time Polymerase Chain Reaction in Diagnosis of Chronic Myeloid Leukemia. J Coll Physicians Surg Pak. 2014;24(3):190-3.

9. Sultan S, Zaheer HA, Irfan SM, Ashar S. Demographic and Clinical Characteristics of Adult Acute Myeloid Leukemia - Tertiary Care Experience. Asian Pac J Cancer Prev. 2016;17 (1):357-60.

10. Savasoglu K, Payzin KB, Ozdemirkiran F, Berber B. Effectiveness of Quantitative Real Time PCR in Long-Term Follow-up of Chronic Myeloid Leukemia Patients. J Coll Physicians Surgeons Pak. 2015;25(8):568-72.

11. Bashir M, Zaman S, Rafatullah, Wazir F, Shoaib W, Biland B. Hematological and Clinical Presentation of Acute Leukemias At Khyber Pukhtoonkhwa. Gomal J Med Sci. 2010;8(2):134-40.

12. Ahmad SQ, Yusuf R, Burney $S$. Frequency of Various Types of Leukaemias Diagnosed At PAF Hospital Mianwali. Pak Armed Forces Med J. 2015; 65(4): 474-77.

13. Ahmed I, Assad S, Ghazanfar H. Flow Cytometric Analysis: Four-Year Experience in a Tertiary Care Centre of Pakistan. Cureus 2016;8(9):e764.

\footnotetext{
AUTHOR AFFILIATION:

Dr. Faheem Ahmed Memon

Lecturer, Department of Pathology

Liaquat University of Medical \& Health Sciences

(LUMHS), Jamshoro, Sindh-Pakistan.

Dr. Amir Iqbal Memon (Corresponding Author)

Associate Professor, Department of Surgery

LUMHS, Jamshoro, Sindh-Pakistan.

Email: dr_amiriqbalmemon@yahoo.com

Dr. Pushpa

Assistant Professor

Muhammad Medical College

Mirpurkhas, Sindh-Pakistan.
}

\section{Dr. Nisar Ahmed}

Assistant Professor, Department of Medicine Muhammad Medical College

Mirpurkhas, Sindh-Pakistan.

\section{Dr. Roohi Nigar}

Lecturer, Department of Gynae Obs.

Isra University Hyderabad, Sindh-Pakistan.

\section{Dr. Ikramdin Ujjan}

Professor, Department of Pathology

LUMHS, Jamshoro, Sindh-Pakistan. 